\title{
Corporate Governance and Reliability of Financial Reporting in Central Government Agencies
}

\author{
María-José Arcas-Pellicer ${ }^{(\dagger)}$, Vicente Pina $^{a}$, Lourdes Torres $^{\mathbf{a}},{ }^{b}$ \\ a) Departamento de Contabilidad y Finanzas, Facultad de Economía y Empresa, Universidad de Zaragoza, Zaragoza, SPAIN
}

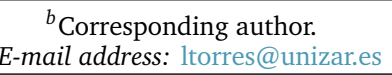

\section{A R T I C L E I N F O}

\section{Article history:}

Received 31 October 2019

Accepted 14 July 2020

Available online 1 January 2022

\section{JEL classification:}

G34

H83

M41

Keywords:

Corporate governance

Abnormal accruals

Central government agencies

Spain

\section{A B S T R A C T}

The objective of this paper is to determine the effects of the corporate governance practices of central government agencies on the reliability of nancial reporting. There has been a considerable growth of these agencies across countries, and there are no studies about the relationship between the features of their corporate governance and the level of reliability of their financial reports. This paper provides evidence of systematic upward earnings management by agencies that apply the Private Sector Chart of Accounts to improve their financial performance and to compensate for the reduction of revenues during the worst years of the financial crisis. The results also show that abnormal accruals have a significant and inverse relationship with the percentage of independent directors and women on the boards, i.e., diversity improves the reliability of the financial information of these entities.

(C)2022 ASEPUC. Published by EDITUM - Universidad de Murcia. This is an open access article under the CC BY-NC-ND license (http://creativecommons.org/licenses/by-nc-nd/4.0/).

Gobierno Corporativo y Fiabilidad de la Información Financiera en las Agencias Gubernamentales Estatales

RE S U M E N

El objetivo de este trabajo es determinar los efectos que tienen las prácticas de gobierno corporativo de las agencias públicas estatales sobre la fiabilidad de su información financiera. Se ha producido un considerable aumento de estas agencias en muchos países; sin embargo, no hay estudios sobre la relación entre las características de su gobierno corporativo y el nivel de fiabilidad de sus estados financieros. Este artículo proporciona evidencia de que hay una estrategia de aumentar el resultado entre las agencias que aplican el Plan General de Contabilidad, para mejorar su rendimiento financiero y compensar la reducción de ingresos durante los peores años de la crisis financiera. En relación al gobierno corporativo, los resultados también muestran que los devengos discrecionales tienen una relación inversa significativa con el porcentaje de consejeros independientes y mujeres en los consejos, esto es, la diversidad del consejo mejora la fiabilidad de la información financiera de estas entidades.

(C)2022 ASEPUC. Publicado por EDITUM - Universidad de Murcia. Este es un artículo Open Access bajo la licencia CC BY-NC-ND (http://creativecommons.org/licenses/by-nc-nd/4.0/). 


\section{Introduction}

Many empirical studies have documented earnings management practices in business companies and provide evidence that they are common across countries in order to avoid losses or decreases in results. For Healy \& Wahlen (1999), earnings management occurs "when managers use judgment in financial reporting and in structuring transactions to alter financial reports to either mislead some stakeholders about the underlying economic performance of the company or to influence contractual outcomes that depend on reported accounting numbers". Motivations for earnings management exist both in the private and the public sector, although with different purposes (Brickley \& Van Horn, 2002). Pina, Arcas \& Martí (2012) found evidence of earnings management in UK executive agencies; Leone \& Van Horn (2005), and Ballantine, Forker, \& Greenwood (2007) in private hospitals and the National Health Service trusts; Stalebrink (2007), Pilcher \& Van der Zahan (2010), and Ferreira, Carvalho, \& Pinho (2009) in local governments, Trussel (2003) in charitable organizations, and Wang \& Yung (2011), Gaio \& Pinto (2018) and Capblo, Frino, Mollica, \& Palumbo (2014) in state-owned companies. All these studies in the public and non-profit sector indicate that there is a significant use of accounting numbers management and show that CEOs manage operating income in a narrow range just above zero to avoid losses.

According to Larcker, Richardson, \& Tuna (2007), measures of abnormal accruals are typically used as surrogates for earnings quality (e.g., Klein, 2002). The flexibility afforded through accrual accounting makes the accrual component of earnings less reliable than the cash flow component and, therefore, a potentially useful measure for examining the quality of financial reports. Public sector managers may find incentives to use discretionary accruals to disguise poor financial performance, management deficiencies or funding insufficiencies in the delivery of public services, increases in service costs or in deficits, decreases in traditional surpluses and negative non-expected results in financial and non-financial forecasted performance measures (Pina et al., 2012).

The relationship between the parent ministry (principal) and the managers or CEOs of their agencies ${ }^{1}$ (agents) can be described as an agency relationship (Jensen \& Meckling, 1976). Although the accounting system has always been closely linked to the agency problem, accountability relationships between principals and agents in the public sector have been shown to be more complex than in the private sector, open-ended or not explicitly defined. Thus, they are not easily monitored (Pina, Torres, \& Yetano, 2009). For Batley \& Larbi (2004), a multi-layer agency problem exists in the public sector, where the citizens are "the principals over political policymakers as their agents and policymakers are the principals over public service officials as their agents". An agency is expected to achieve the desired level of efficiency and performance as well as to serve social and policy objectives (Shawtari, Mohamad, Rashid, \& Ayedh, 2017). Central government issues guidelines and directives expressed in terms of the general goals and main lines of development of agency activities. To achieve them, agencies are given managerial freedom and flexibility in the use of resources. In this

\footnotetext{
${ }^{1}$ Agencies is a commonly used term covering a wide range of public arm's-length bodies, including non-ministerial departments, nondepartmental public bodies, executive agencies and other bodies, such as public corporations. The size and role of agencies vary hugely. Agencies range from large executive agencies to small non-departmental public bodies (NAO, 2016).
}

scenario, both Ministers and CEOs can be considered as selfinterested and maximizing agents, and both bear and share costs.

According to the positive accounting theory, earnings management practices occur mainly because principal-agent contracts include accounting figures (Beattie, 2002). Agents would find incentives for earnings management in order to give the best view of their performance, for professional prestige and for the maintenance of their jobs (Watts \& Zimmerman, 1986). In the public sector, where maximizing earnings is not an objective, net income is a measure of good management. Because of this, 'accounting numbers management' also emerges in the public sector as an attractive way of making accounting figures friendly to managers' interests for achieving break-evens, targets agreed with parent entities or the fulfilment of goals included in political campaign programs and/or strategic management plans.

To hold managers accountable, a positive effect of corporate governance (CG) codes on financial reporting has been found by most empirical research in the private sector (Bhagat \& Black, 2002; Borisova, Brockman, Salas, \& Zagorchev, 2012). A major reason for this research interest in the last two decades has been the demand for greater managerial accountability and responsibility after a number of accounting scandals in the private sector (Agrawal \& Chadha, 2005). In the public sector, although the composition of boards is less regulated than in private sector firms, CG mechanisms are becoming very popular as a result of the financial crisis and recent scandals affecting public sector management (Christopher, 2010). In 1995, a document issued by the Chartered Institute of Public Finance and Accountancy (CIPFA, 1995) concluded that the issues raised in the Cadbury Report on governance in corporations were also relevant to public sector organizations and urged them to adopt the Cadbury principles. According to Hodges, Wrightand, \& Keasey (1996), the Cadbury Report has influenced a number of recommendations from the UK accounting bodies (for example CIMA, ICAEW, ICAS, CIPFA) while discussion papers and codes of conduct have been issued relating to public service activities (Nolan, 1995).

At the moment, there are several studies about the quantity of information disclosed in public sector entities (Royo, Yetano, \& García-Lacalle, 2019) but there are no studies about the relationship between the features of CG and the level of reliability of financial reports of public entities. Most academic studies about each of these two fields are based on the agency theory, which provides theoretical consistency. Both the reliability of financial reports and CG are closely linked in the public sector to the asymmetry of information between governments (agents) and citizens and other stakeholders (principals). For Filgueiras (2015), accountability is improved by allowing the reduction of information asymmetry between governments and citizens.

The objective of this paper is to determine the relation between board characteristics and financial reporting reliability for the Spanish central government agencies. These entities are required by the central government to make a financial break-even to fulfil the limits of deficit and debt agreed with the European Commission. Given that management discretion exists in the form of accounting choices, estimates and disclosures, even within generally accepted accounting principles, we examine whether board characteristics are associated with abnormal accruals (a proxy for nancial reporting reliability).

The contribution of this study to previous literature is that the relation between abnormal accruals and board character- 
istics is analyzed in an absolutely different institutional environment to the private sector. In the public sector, various layers of agency relationship can be found, so the study provides a more powerful test of the relation between governance characteristics and abnormal accruals. In some OECD countries, agencies controlled by the central government account for more than $50 \%$ of public expenditure and public employment (OECD, 2005). Although new public management reforms encouraged the creation of independent organizations for the delivery of public services, the control over senior managers is crucial for holding them accountable. The relation between CG and the quality of financial reporting is important to practitioners, academics and policy makers.

\section{Governance and Financial Structure of the Spanish Central Government Agencies}

Spanish agencies produce goods or deliver services to external customers, citizens or other public entities, offer research services and carry out monitoring or regulatory activities. Like the UK agencies (NAO, 2003), these entities operate at arm's length from their parent ministries and have considerable autonomy and freedom of action. This freedom is accompanied by obligations to meet annual specific financial and operational targets, agreed with the Minister, directed at achieving specific outcomes, financial management and the quality of service delivered. In this framework, it is assumed that control through detailed appropriation of inputs is replaced by performance targets. In 2015, there were in Spain 168 central government agencies -10 executive agencies, 59 autonomous bodies, 26 joint ventures, 13 business-like entities working under commercial law and 60 other agencies, hybrid bodies under the mixed legal forms of joint ventures and/or business-like entities. Altogether they represent more than 27 per cent of national civil servants and manage 30 per cent of central government expenditure.

The executive agencies, created under the Act 28/2006, represent the most recent type of independent public body set up by the central government, with a management system closer to private sector CG and the New Public Management doctrines. According to this law, all executive agencies should be managed through a board of directors and, at least, an executive committee, a control committee and an advisory council. The autonomous bodies, created on the basis of a legal framework prior to the Act 28/2006, present quite different goals and missions. Their board of directors is defined with less detail as in the first case. The joint venture entities are created by central, regional and/or local governments to manage or develop common interest specific activities. Because of this, the boards of directors and the percentage of independent directors tend to be bigger than in the other types of public bodies. Business-like entities are public entities, which work under commercial law requirements and adopt business-like governing bodies and management systems. Finally, under the label of other agencies, there are public entities with very different goals and missions, ranging from regulatory entities, harbour authorities, language and literature institutes, museums and academic institutions. Most of them were created before 2006.

Even though variations in the CG profile can be found between and within the five types of agencies, according to their specific creation statute, their CG profile is made up of a President, a Board of Directors and, in some cases, an Advisory Council and some committees. The President is appointed by the parent ministry. The Board of Directors is made up of the President, the CEO and members appointed by the parent ministry and, when applicable, by other ministries, regions, municipalities, the private sector and trade unions. The Board of Directors may appoint a Permanent Committee and a Control Commission together with other commissions or committees for the development of specific activities. Notwithstanding, their specific composition is established in the creation statute of each entity. The CEOs are appointed by ministers for a fixed term and there is usually an element of performance-related pay in their remuneration. They are personally responsible for day-to-day operations and directly accountable to the responsible minister who, in turn, is accountable to Parliament.

With respect to funding structure, executive agencies and joint ventures have a strong dependence on the financial support of the central government, receiving operating grants which represent more than $78 \%$ and $90 \%$ of their respective total revenues. The grants received by the autonomous bodies and other agencies are around 50\% of their respective revenues and only business-like entities fund most of their activities with revenues from the delivery of goods and services (around 70\%). Between 2012 and 2015, Spain had to control its budgetary deficits, resulting in a decreased contribution of grants to the total funding of the agencies.

Because of their different funding structure and objectives, executive agencies, autonomous entities, joint ventures and some hybrid organizations (related to genuine public sector activities) follow the accounting and disclosure requirements of the Spanish Public Sector Chart of Accounts, whereas business-like entities and some hybrid organizations apply the Private Sector Chart of Accounts.

Motivations for accounting numbers management may be different between both groups and also the relationship between earnings quality and CG structure. For those applying the Public Sector Chart of Accounts (executive agencies, autonomous entities and joint ventures) obtaining surpluses is not their objective. They need to signal that they meet their objectives and provide public services at a reasonable cost Also, they need to justify funding from parent ministries and, because of this, they will often be set targets to break-even after all costs have been met (Pina et al., 2012). Those applying the Private Sector Chart of Accounts (business-like entities, mainly) are interested to signal that they are financially independent from the parent ministry and economically viable in the long-term. As a result, for them, obtaining profits is important.

Because of these differences, in this paper we analyze earnings management differentiating both types of entities, those that apply the Public Sector Chart of Accounts from those that apply the Private Sector Chart of Accounts.

\section{Theoretical Framework and Hypotheses}

\subsection{A Multi-Theoretical framework}

Agency theory suggests the disclosure of information as a means to reduce information asymmetry between principals and agents and it sees managers as accountable to principals. However, in the public sector, managers rather than accountable to principals are publicly accountable to and under the scrutiny of citizens and stakeholders. For Normanton (1971), to be publicly accountable implies making the accountability process accessible to outside parties, rather than being an internal issue between principal and agent as it is in the private sector. According to Calabro, Torchia, \& Ranalli (2013) and Shawtari et al. (2017), there are multiple players in public entities, including citizens, the local government, private in- 
vestors and governing entities. Citizens are considered as the principal and the public entities' managers act as their agent to protect the public interest (Hinna, De Nito, \& Mangia, 2010; Lane, 2005). However, given that managers are mostly politically linked, and they are likely to serve their own political interests and/or the political interest of the Minister who appointed them, the principal's interest is not maximized in a situation where the agent is motivated by self-interest rather than public interest (Batley \& Larbi, 2004; Shawtari et al., 2017). Calabro et al. (2013) state that, since the separation between citizen and principal is very high, the possibility of opportunistic behavior is strong. The ability of the principal to curb opportunistic behavior depends on how much information it has about the performance of the agent and the quality of the information available. In this complex situation, the board of directors is required to perform multiple functions: to safeguard public interest, to guarantee protection to stakeholders, and to ensure the quality of the information disclosed and compliance with the law (Gnan, Hinna, Monteduro, \& Scarozza, 2011).

Even though the agency theory has traditionally been considered the basis for the design of CG structures, other theories are also being gradually applied to explain the disclosure and quality of information in the public sector. This is the case of legitimacy and stakeholder theories (Ntim, Soobaroyen, \& Broad, 2017; Mahadeo, Oogarah-Hanuman, \& Soobaroyen, 2011). Legitimacy theory (Ashforth \& Gibbs, 1990; Suchman, 1995) sees increased quality of information as the way managers show public accountability and consistency with the goals and objectives of the entity, with positive consequences for the image and the reputation of the entity among stakeholders. Stakeholder theory states that increased quality of information can be seen as an indicator of public accountability and commitment to the users of the service (Coy \& Dixon, 2004). This may be an important way of improving the trust of citizens, other tiers of the public administrations, businesses, civil associations and other stakeholders in the public entity (Freeman \& Reed, 1983; Freeman, 1984; Donaldson \& Preston, 1995; Michelon \& Parbonetti, 2012).

Agency and legitimacy theories see the disclosure of reliable information to outside parties as a tool to show the fulfilment of duties and responsibilities, while stakeholder theory considers the benefits from the disclosure of reliable information in terms of gaining support from community actors (e.g., regional and local governments, trade unions, business and civil associations). Legitimacy and stakeholder theories include, beside principals and agents (i.e. governors and managers), other parties interested in the activities of public entities for political, economic or social reasons (Demb \& Neubauer, 1992).

\subsection{Hypotheses}

The academic literature identifies a number of characteristics of the board of directors as relevant for explaining the accountability and financial reporting of entities. Almost all the empirical evidence comes from the private sector. In the public sector, very few papers analyze the features of boards of director and only focus on state-owned companies. For example, for Reddy, Locke, \& Scrimgeour (2011), the board of directors is a key mechanism of CG for monitoring and holding managers accountable in New Zealand state-owned companies.

\subsubsection{Size of the Board}

The empirical evidence supports that the number of directors is a relevant factor that could condition the activities of monitoring and control of the accountability process of the entity, even though the results are not conclusive. From a stakeholder theoretical perspective, large governing boards may be able to represent a wider group of key parties and actors interested in the activities of the entity (Freeman \& Reed, 1983; Freeman, 1984). Goodstein, Gautam, \& Boeker (1994) and Reddy et al. (2011) argued that larger boards tend to provide an increased pool of expertise and diversity and a higher level of risk disclosure (Allini, Rossi, \& Hussainey, 2016). The effectiveness of boards to represent the different interests and views of stakeholders will depend on having a sufficient number of board members to attend the demands of and to provide the information required by them. From a legitimacy theory perspective, the statutorial composition of boards may seek legitimacy in terms of how the organization is structured in accordance with social expectations (Ashforth \& Gibbs, 1990; Suchman, 1995). However, De Pablo, Azofra, \& Lopez (2005) hypothesized that oversized boards lead to worse performance. For Lipton \& Lorsch (1992) and Jensen (1993) the benefits of large boards can be outweighed by the costs in terms of the poorer communication and decision-making associated with larger groups, along with the fact that the CEO may be more likely to control the board of directors. Yermack (1996) and Hossain, Prevost, \& Rao (2001) reported an inverse relationship between board size and rm nancial performance. For Cheng \& Courtenay (2006), there is no theory or empirical evidence to suggest a relation between board size and the reliability of financial information, and the previous literature is not conclusive about the role played by board size in the public accountability processes of entities.

In accordance with Ntim et al. (2017), due to the mixed theoretical and empirical evidence and although previous literature is not conclusive, the two theories that fit better into the public sector framework, the stakeholders and the legitimacy theories, aim at a positive relationship between the size of the board and the reliability of the financial information. So, we hypothesize that the size of the board will be positively related to reliability of the financial information.

Hypothesis 1: Board size is positively associated with the nancial report's reliability of the agency.

\subsubsection{Number of Meetings of the Board}

The number of meetings may be considered an indicator of the control of the board of directors (Carcello et al., 2002; Karamanou \& Vefeas, 2005). Most empirical research on CG indicates that the frequency of board meetings has a positive impact on the reliability of financial information (Allegrini \& Greco, 2013). Board meetings may enhance the information received by the stakeholders' representatives (Freeman \& Reed, 1983; Freeman, 1984), which can help them to address emerging critical problems in a timely manner. By contrast, Jensen (1993) has suggested that regular board meetings may have a negative effect in terms of executive time.

According to legitimacy and stakeholders' theories, above mentioned, the higher number of meetings, the higher control of constituents over the agency managers. So, we hypothesize that the number of meetings per year may be positively related to reliability. 
Hypothesis 2: The number of meetings per year is positively associated with financial report's reliability of the agency.

\subsubsection{Board Committees}

The appointment of board committees is expected to have a positive effect on agencies. Empirical research about board committees has been associated with better performance (McMullen, 1996; Klein, 1998), although it is not conclusive (Reddy et al., 2011).

According to legitimacy and stakeholders' theories, the higher number of board committees, the higher control of constituents over the agency managers. So, we hypothesize that the number of committees may be positively related to reliability. So, we hypothesize that the number of board committees will be positively related to reliability,

Hypothesis 3: The number of board committees is positively associated with financial report's reliability of the agency.

\subsubsection{Composition of the Board: Percentage of Independent Directors}

According to Coy, Fischer \& Gordon (2001), the presence of independent directors on the boards can enhance managerial monitoring and thereby help to improve public accountability. Their presence suggests a stakeholder approach to financial information reliability through which the public sector-controlled bodies provide financial information for different interest groups. Stakeholder theory indicates that the appointment of independent directors with a good reputation may be a symbol of openness and transparency. Legitimacy theory suggests that one way of bringing the organization and its stakeholders closer is to appoint independent directors representative of those stakeholders (Ashforth \& Gibbs, 1990; Suchman, 1995).

For Allini, Rossi, \& Hussainey (2016), independent directors may help to reduce information asymmetry. They are usually professionals who have neither a management role nor a relationship to the entity and who often have a reputation for professional integrity to protect. Independent directors promote global relationships and board independence because people with different backgrounds, representing different stakeholders, provide new insights and perspectives (Coffey \& Wang 1998), increase discussion, promote the exchange of ideas (Van Knippenberg, De Dreu, \& Homan, 2004) and improve organizational value (Carter, Simkins, \& Simpson, 2003). This paper considers that independent directors come from other tiers of the public administration, such as regional and local governments, and directors who do not come from the public administration but from trade unions, NGOs, civil associations and industries. Therefore, independent directors represent different stakeholder interests and may seek to influence the organization's response to their demands (Ntim et al., 2017). Non-independent directors are those appointed by the parent ministry and/or by other central government ministries.

A positive relationship between independent directors and the reliability of financial information is hypothesized since they should strengthen the accountability dimension of CG.

Hypothesis 4: The percentage of independent directors from the central government is positively associated with financial report's reliability of the agency.

\subsubsection{Gender Diversity}

According to empirical research on CG, diversity on the board of directors in terms of visible characteristics such as gender, age or ethnicity or non-visible characteristics such as academic, professional and political background, can offer corporations a number of benefits including additional knowledge, fresh ideas and insights to aid problem-solving, better product positioning, enhanced strategic planning, new knowledge or opinions, and even additional accountability (Arfken, Bellar, \& Helms, 2004; Mahadeo et al., 2011). Similarly, Jensen (1993) considers that the diversity on boards can contribute to protecting the public interest (Coy, Fischer, \& Gordon, 2001).

Gender is currently the most debated diversity topic. From the agency perspective, gender would not affect the effectiveness of a board (Allini, Rossi, \& Hussainey, 2016). Notwithstanding, the presence of female directors in SOEs is receiving increasing attention (Ellwood \& Garcia-Lacalle, 2015). Araujo \& Tejero-Romero (2016) find a positive relationship between female representation in municipalities and their level of transparency. We focus on gender aspects of the boards of directors in terms of the percentage of women. In Spain, ethnicity and age are not relevant issues because there is a strong homogeneity in the population and most board directors are civil servants and/or politicians between sixty-five and seventy years old.

Hypothesis 5: The percentage of women is positively associated with financial report's reliability of the agency.

\subsubsection{Board Independence}

The independence of the directors is defined as a dummy variable that takes a value of 1 if the board is controlled by a majority of directors that are independent from the parent ministry of the agency and zero otherwise. The results of the empirical research into the effect of board independence on the reliability of financial information is not conclusive. Denis \& Sarin (1999), Hossain, Prevost, \& Rao (2001) and Rosenstein \& Wyatt (1990) find a positive relationship between board composition and nancial performance while Agrawal \& Knoeber (1996); Bhagat \& Black (1998); Reddy, Locke, Scrimgeour, \& Gunasekarage (2008), and Yermack (1996) find a negative one. Other studies (Byrd \& Hickman, 1992; Chin, Vos, \& Casey, 2003; Daily \& Dalton, 1992; Mace, 1986) find no relationship between them.

Following the legitimacy and stakeholders' theories, a positive relationship between the independence of the board and the reliability of financial information is hypothesized. When more than $50 \%$ of directors are not appointed by the parent ministry and/or by other central government ministries, the likelihood that the financial report is provided without political bias is higher, and then the reliability of financial information is increased.

Due to the multicollinearity between "board independence" and "the percentage of independent directors", the second considered a proxy of the first by some authors, two multivariate models will be defined introducing only one of the variables into each model.

Hypothesis 6: Board independence is positively associated with financial report's reliability of the agency. 


\section{Sample and Methodology}

\subsection{Sample and Data}

Our sample includes all Spanish central government agencies, existing from 2011 to 2015, with available accounting and CG information to calculate the necessary variables. Public sector foundations, Social Security entities, and financial and insurance entities have been excluded due to the nature of their financial reporting rules. Our final sample consists of 481 entity-year observations belonging to 110 agencies with available data in at least one year. Among these observations, 290 belong to entities that apply the Public Sector Chart of Accounts and 191 that apply the Private Chart of Accounts. The accounting data used in the study come from the financial reports issued between 2011 and 2015, approved by the Spanish National Audit Office and published either by the Internal Audit Office, the $\mathrm{IGAE}^{2}$, or in the Spanish official gazette (BOE).

\subsection{Methodology}

First, we estimate abnormal accruals for each agency-year as proxy for financial reporting reliability. Second, we carry out a panel data regression in order to determine the relationship between abnormal accruals and board of directors' characteristics.

Abnormal accruals are defined as the component of accruals that is under management's discretion (accounting choices, estimates and disclosures), even within generally accepted accounting principles. Because abnormal accruals are unobservable, they are estimated as the difference between total accruals and expected accruals. For Hribar, \& Collins (2002), the frequency and magnitude of errors when using balance sheet-based accruals estimates might be substantial and, because of this, they suggest the use of accruals taken from the cash-flow statement. Following this approach, we calculate total accruals as the difference between net income and net cash flows from operating activities:

$$
A C C R_{j t}=N I O_{j t}-C F O_{j}
$$

where NIOjt is the net income from operating activities of agency $j$ in year $t$ and CFOjt is the net cash-flow from operating activities of agency $j$ in year $t$.

To estimate discretionary accruals, we use the crosssectional version of the Jones model (Jones, 1991) modified by Dechow, Sloan, \& Sweeney $(1995)^{3}$ :

$$
\begin{aligned}
A C C R_{i t} / T A_{j t-1}= & \alpha_{1}\left(1 / T A_{j t-1}\right) \\
& +\alpha_{2}\left(\Delta R E V_{j t}-\Delta A R_{j t}\right) / T A_{j t-1} \\
& +\alpha_{3}\left(P P E_{j t} / T A_{j t-1}\right)+\varepsilon_{j t}
\end{aligned}
$$

where,

$A C C R_{i t}=$ Total accruals of agency $\mathrm{j}$ in year $\mathrm{t}$,

$T A_{j t-1}=$ Total assets of agency $\mathrm{j}$ at the end of year $\mathrm{t}-1$

$\triangle R E V_{j t}=$ Change in revenues of agency $\mathrm{j}$ in year $\mathrm{t}$,

$\Delta A R_{j t}=$ Change in accounts receivable of agency $\mathrm{j}$ year $\mathrm{t}$

$P P E_{j t}=$ Gross property, plant and equipment of agency $\mathrm{j}$ in year $\mathrm{t}$

${ }^{2}$ On the website http://www.igae.pap.hacienda.gob.es/sitios/igae/ es-ES/BasesDatos/ClnInvespe/Paginas/invespe.aspx

${ }^{3}$ Reguera, Laffarga, \& De Fuentes (2015) find that these models are wellspecified and robust in the Spanish context. As a robustness analysis, we have also used the Kasznik model (Kasznik, 1999) finding the same results.
Consistent with prior literature and to reduce estimation problems, all variables are scaled by lagged total assets.

Change in revenues controls for the economic environment of the entity because total accruals include changes in working capital such as receivables and payables related to change in revenues (Jones, 1991). Gross property, plant and equipment are related to total accruals through amortization expenses.

We estimate equation (1) for each year using OLS regression. The fitted value of the regression is the estimated expected accruals (the non-discretionary component of total accruals), and the difference between the observed value and the fitted value is the estimated abnormal accruals (DAjt), both scaled by lagged total assets, which is our measure of financial reporting reliability.

According to hypotheses previously developed, our models for the relationship between abnormal accruals and corporate governance characteristics are:

$$
\begin{aligned}
D A_{j t}= & \beta_{0}+\beta_{1} \text { SIZE }_{j}+\beta_{2} \text { MEETINGS } \\
& +\beta_{3} \text { COMMITTEES }_{t}+\beta_{4} \text { WOMAN }_{t} \\
& +\beta_{5} \text { INDEPDIR }_{t}+\varepsilon_{j t} \\
\text { DA }_{j t}= & \gamma_{0}+\gamma_{1} \text { SIZE }_{j}+\gamma_{2} \text { MEETINGS }_{t} \\
& +\gamma_{3} \text { COMMITTEES }_{t}+\gamma_{4} \text { WOMAN }_{t} \\
& +\gamma_{5} \text { BINDEP }_{t}+\varepsilon_{j t}
\end{aligned}
$$

where,

$D A_{j t}=$ Abnormal accruals scaled by lagged total assets of agency $\mathrm{j}$ in year $\mathrm{t}$,

$S I Z E_{j}=$ Number of directors on the board of agency $\mathrm{j}$ $M E E T I N G S_{j}=$ Number of meetings per year of agency $\mathrm{j}$,

COMMITTEES $S_{j}=$ Number of board committees of agency $\mathrm{j}$

$W O M A N_{j}=$ The proportion of women on the board of agency $\mathrm{j}$

$I N D E P D I R_{j}=$ The proportion of directors on the board of agency $\mathrm{j}$ that are independent from the central government

$B I N D E P_{j}=$ Dummy for board independence $(=1$ if the board is controlled by a majority of directors that are independent from the parent ministry of agency $\mathrm{j}, 0$ otherwise) for agency $\mathrm{j}$

For each entity, these characteristics do not change across the period analyzed. For this reason, we omit the subscript for time in the independent variables.

We estimate these models using panel data regression.

\subsection{Analysis of Results}

\subsubsection{Estimation of Abnormal accruals}

Table 1 shows summary statistics for the variables included in regression (1). As it can be seen, in 2011, there has been a great decrease in revenues with a mean (median) of $-40.9108(-1.7152)$ and high dispersion (the standard deviation is 117.52). In 2012 and 2013, there is a lower decrease of revenues with a mean (median) of $-0.1107(-0.0107)$ and -0.0035 (-0.0030), respectively. In 2014 and 2015, revenues increase with a mean (median) of 0.0015 (0.0010) and 0.0213 (0.0060), respectively. The evolution of revenues reflects the general evolution of the Spanish economy and 
the central government budget during these years in which the financial crisis brought about a substantial reduction of central government tax revenues and, because of this, the reduction of the revenues of agencies. The mean for accruals $\left(A C C R_{i t} / T A_{j t-1}\right)$ ranges from -0.0473 in 2015 to -0.0146 in 2011 with the highest (lowest) standard deviation in 2014 (2011). Finally, descriptive statistics for gross property, plant and equipment are similar in all years.

Table 1. Summary statistics

\begin{tabular}{|c|c|c|c|c|c|}
\hline & Mean & Median & Std.Dev. & Min. & Max. \\
\hline \multicolumn{6}{|l|}{ Year $2011(\mathrm{~N}=105)$} \\
\hline ACCRjt/TAjt-1 & -0.0146 & -0.0198 & 0.1144 & -0.2637 & 0.5483 \\
\hline$\left(\Delta \mathrm{REV}_{\mathrm{jt}}-\Delta \mathrm{AR}_{\mathrm{jt}}\right) / \mathrm{TA} \mathrm{A}_{\mathrm{jt}-1}$ & 40.9108 & -1.7152 & 117.5196 & -754.2448 & 0.4197 \\
\hline $\mathrm{PPE}_{\mathrm{jt}} / \mathrm{TA}_{\mathrm{jt}-1}$ & 0.8506 & 0.9479 & 0.5947 & 0.0000 & 4.2310 \\
\hline \multicolumn{6}{|l|}{ Year $2012(\mathrm{~N}=102)$} \\
\hline ACCRjt/TAjt-1 & -0.0308 & -0.0237 & 0.1526 & -0.4687 & 0.9835 \\
\hline$\left(\Delta \mathrm{REV}_{\mathrm{jt}}-\Delta \mathrm{AR}_{\mathrm{jt}}\right) / \mathrm{TA} \mathrm{A}_{\mathrm{jt}-1}$ & -0.1107 & -0.0107 & 0.3690 & -2.7876 & 0.1485 \\
\hline $\mathrm{PPE}_{\mathrm{jt}} / \mathrm{TA}_{\mathrm{jt}-1}$ & 0.8382 & 0.9584 & 0.4655 & 0.0000 & 1.6929 \\
\hline \multicolumn{6}{|l|}{ Year $2013(\mathrm{~N}=97)$} \\
\hline ACCRjt/TAjt-1 & -0.0329 & -0.0246 & 0.1486 & -0.7450 & 0.7761 \\
\hline$\left(\Delta \mathrm{REV}_{\mathrm{jt}}-\Delta \mathrm{AR}_{\mathrm{jt}}\right) / \mathrm{TA}_{\mathrm{jt}-1}$ & -0.0035 & -0.0030 & 0.1155 & -0.5309 & 0.3832 \\
\hline $\mathrm{PPE}_{\mathrm{jt}} / \mathrm{TA}_{\mathrm{jt}-1}$ & 0.8484 & 0.9603 & 0.5005 & 0.0000 & 2.0283 \\
\hline \multicolumn{6}{|l|}{ Year $2014(\mathrm{~N}=98)$} \\
\hline ACCRjt/TAjt-1 & -0.0424 & -0.0236 & 0.2309 & -2.1207 & 0.6767 \\
\hline$\left(\Delta \mathrm{REV}_{\mathrm{jt}}-\Delta \mathrm{AR}_{\mathrm{jt}}\right) / \mathrm{TA}_{\mathrm{jt}-1}$ & 0.0015 & 0.0010 & 0.1731 & -0.9022 & 1.0516 \\
\hline $\mathrm{PPE}_{\mathrm{jt}} / \mathrm{TA}_{\mathrm{jt}-1}$ & 0.8894 & 0.9882 & 0.5152 & 0.0000 & 1.9442 \\
\hline \multicolumn{6}{|l|}{ Year $2015(N=79)$} \\
\hline ACCRjt/TAjt-1 & -0.0473 & -0.0218 & 0.1976 & -1.5591 & 0.1991 \\
\hline$\left(\Delta \mathrm{REV}_{\mathrm{jt}}-\Delta \mathrm{AR}_{\mathrm{jt}}\right) / \mathrm{TA} \mathrm{A}_{\mathrm{jt}-1}$ & 0.0213 & 0.0060 & 0.1970 & -1.1503 & 0.7892 \\
\hline $\mathrm{PPE}_{\mathrm{jt}} / \mathrm{TA}_{\mathrm{jt}-1}$ & 0.9106 & 0.9971 & 0.5501 & 0.0006 & 2.6221 \\
\hline
\end{tabular}

$A C C R_{j t}=$ Total accruals for agency $\mathrm{j}$ in year $\mathrm{t}, T A_{j t-1}=$ Total assets for agency $\mathrm{j}$ at the end of year $\mathrm{t}-1, \Delta R E V_{j t}=$ Change in revenues for agency $\mathrm{j}$ in year $\mathrm{t}, \triangle A R_{j t}=$ Change in accounts receivable for agency $\mathrm{j}$ in year $\mathrm{t}$, and $P P E_{j t}=$ Gross property, plant, equipment for agency $\mathrm{j}$ in year $\mathrm{t}$.

We estimate equation (1) for each year in the period 20112015 winsorizing the regression variables by year so that the minimun and maximum values of each variable lie within three standard deviations from its mean in order to mitigate outlier effects, as in Bartov et al (2000), Tucker \& Zarowin (2006) and Verbruggen et al. (2012). The residuals of these regressions are the estimated discretionary accruals. Table 2 reports the binomial test results for differences between the proportion of positive and negative discretionary accruals by year. The results show that for agencies that apply the Private Sector Chart of Accounts (PrCA) the proportion of positive abnormal accruals is significantly higher than the proportion of negative abnormal accruals in all years except for 2015. Yet, for agencies that apply the Public Sector Chart of Accounts (PSCA) there is no significant difference between positive and negative abnormal accruals.

This result shows evidence of systematic upward earnings management activity during the 2011-2014 period, but only for PrCA agencies. This does not necessarily mean that there is no earnings management activity in PSCA agencies, but that in this group there is no pattern of behavior (earnings increase or earnings decrease). This result is consistent with the different objectives and funding structure of these two groups as previously presented.

\subsubsection{Board Characteristics and Abnormal Accruals}

Table 3 shows descriptive statistics about the board of director characteristics of the 110 agencies included in the sample. As can be seen, their size and composition vary between entities that apply the PSCA and those that apply the PrCA.
Table 2. Binomial tests for differences between the proportion of positive and negative discretionary accruals

\begin{tabular}{|c|c|c|c|c|}
\hline \multirow[b]{2}{*}{ Year } & \multicolumn{2}{|r|}{ PSCA $^{1}$ sample } & \multicolumn{2}{|r|}{ PrCA $^{2}$ sample } \\
\hline & $\mathrm{N}$ & \%positive(p-value) & $\mathrm{N}$ & \%positive (p-value) \\
\hline 2011 & 64 & $51.6 \%(.901)$ & 41 & $78.0 \%(.000) * * *$ \\
\hline 2012 & 59 & $49.2 \%(1.000)$ & 43 & $86.0 \%(.000)^{* * * *}$ \\
\hline 2013 & 57 & $54.4 \%(.597)$ & 40 & $85.0 \%(.000) * * *$ \\
\hline 2014 & 57 & $42.1 \%(.289)$ & 41 & $75.6 \%(.001)^{* * * *}$ \\
\hline 2015 & 53 & $49.1 \%(1.000)$ & 26 & $61.5 \%(.327)$ \\
\hline
\end{tabular}

${ }^{1}$ PSCA: Entities that apply the Public Sector Chart of Accounts.

${ }^{2}$ PrCA: Entities that apply the Private Chart of Accounts.

Significance level: ${ }^{* * *} p<.01$.

Table 3. Board of Director profile of Spanish Central Government Agencies

\begin{tabular}{lllllllllll}
\hline & \multicolumn{4}{l}{ PSCA entities $(\mathrm{N}=66)^{\mathrm{a}}$} & & \multicolumn{3}{c}{ PrCA entities $(\mathrm{N}=45)^{\mathrm{a}}$} \\
\cline { 2 - 8 } & Min & Max & Mean & SD & & Min & Max & Mean & SD \\
\hline SIZE & 4 & 61 & 18.80 & 12.33 & 6 & 21 & 15.73 & 3.32 \\
MEETINGS & 1 & 30 & 2.70 & 4.83 & 1 & 12 & 3.13 & 4.17 \\
COMMITTEES & 0 & 13 & 1.15 & 1.86 & 0 & 6 & 0.53 & 1.12 \\
WOMAN & 0.00 & 0.56 & 0.13 & 0.18 & 0.00 & 0.54 & 0.22 & 0.14 \\
INDEPDIR & 0.00 & 0.86 & 0.14 & 0.21 & 0.00 & 0.47 & 0.17 & 0.13 \\
BINDEP & 0 & 1 & 0.26 & 0.44 & 0 & 1 & 0.64 & 0.48 \\
\hline
\end{tabular}

${ }^{a}$ One agency (ICEX) applies PSCA until 2011 an PrCA from 2012 and it is included in both groups.

PSCA: Entities that apply the Public Sector Chart of Accounts.

PrCA: Entities that apply the Private Chart of Accounts.

Note: The number of entities in each type may be higher than in other analyses Note: The number of entities in each type mases due to restructuring or creation of entities and missing data.

$S I Z E_{j}$ is the number of directors on the board of agency $\mathrm{j}, M E E T I N G S_{j}$ is the number of meetings per year of agency $\mathrm{j}$, COMMITTEES $\mathrm{C}_{j}$ is the number of board committees of agency $\mathrm{j}, W O M A N_{j}$ is the proportion of women on the board of agency $\mathrm{j}, I N D E P D I R_{j}$ is the proportion of directors on the board of agency $\mathrm{j}$ that are independent from the central government, and $B I N D E P_{j}$ is a dummy for board independence $(=1$ if the board is controlled by a majority of directors that are independent from the parent ministry of agency $\mathrm{j}, 0$ otherwise) for agency $\mathrm{j}$.

The size of the board of directors and the number of committees are, on average, higher for PSCA entities than for PrCA entities, but the most outstanding characteristic is the dispersion. The size of the board ranges between 4 and 61 members for PSCA agencies (with a standard deviation of 12.33) and between 6 and 21 for PrCA agencies (with a standard deviation of 3.32). In addition, the number of committees ranges between 0 and 13 for PSCA agencies (with a standard deviation of 1.86) and between 0 and 6 for PrCA agencies (with a standard deviation of 1.12). The dispersion is also higher in the number of meetings per year for PSCA agencies, that ranges between 1 and 30, whereas in PrCA agencies it ranges between 1 and 12 .

With regards to the composition, the percentage of independent directors is higher on average for PrCA entities than for PSCA entities (means of $17 \%$ and 14\%, respectively). The gender diversity is higher for PrCA agencies than for PSCA agencies. The mean of women is $22 \%$ and $13 \%$, respectively. Nevertheless, the dispersion is higher for PSCA entities than for PrCA entities.

Overall, these results illustrate the heterogeneity of the agencies, not only between the two groups, but also particularly among those applying the PSCA.

Table 4 includes the Pearson correlation matrix for the independent variables of equations (2) and (3), separately for agencies that apply the PrCA in the upper side, and agencies that apply the PSCA and in the lower side. As expected, the highest correlation in both groups is between INDEPDIR and BINDEP because both variables are proxies for board independence. SIZE is positively related to the INDEPDIR and BINDEP in both groups. This is because, depending on the activities of the agencies, their creation statutes include rep- 
Table 4. Pearson Correlation Matrix for the independent variables (p-values in parentheses)

\begin{tabular}{llllllll}
\hline $\begin{array}{r}\text { PrCA agencies } \\
(\mathrm{N}=45)\end{array}$ & & & & & & \\
PSCA agencies \\
(N=66)
\end{tabular}

For a definition of the variables see Table 3

Significance level: ${ }^{*} p<.1,{ }^{* *} p<.05,{ }^{* * *} p<.01$

resentatives from other tiers of the public administration and from the private sector on the board of directors. In these cases, the number of independent directors, who are not directly involved in the management of the agencies, tends to grow. In the PrCA group, the number of meetings per year is negatively related to board independence; this shows that in business-like agencies, boards with more percentage of independent directors meet less frequently than others. Finally, in the PrCA group, the percentage of women is negatively related to the board independence.

Table 5. Relation between abnormal accruals and corporate governance factors

\begin{tabular}{|c|c|c|c|c|}
\hline & \multicolumn{2}{|c|}{$\underline{\text { PSCA sample }(\mathrm{N}=290)}$} & \multicolumn{2}{|c|}{ PrCA sample $(\mathrm{N}=191)$} \\
\hline & $\begin{array}{l}\text { Model } 1 \\
(\mathrm{~N}=290) \\
\text { Estimated } \\
\text { parameter } \\
\text { (z-statistic) } \\
\text { p-value }\end{array}$ & $\begin{array}{l}\text { Model } 2 \\
(\mathrm{~N}=290) \\
\text { Estimated } \\
\text { parameter } \\
\text { (z-statistic) } \\
\text { p-value }\end{array}$ & $\begin{array}{l}\text { Model } 1 \\
(\mathrm{~N}=290) \\
\text { Estimated } \\
\text { parameter } \\
\text { (z-statistic) } \\
\text { p-value }\end{array}$ & $\begin{array}{l}\text { Model } 2 \\
(\mathrm{~N}=290) \\
\text { Estimated } \\
\text { parameter } \\
\text { (z-statistic) } \\
\text { p-value }\end{array}$ \\
\hline & -.030 & -.038 & .112 & $.114^{*}$ \\
\hline \multirow[t]{3}{*}{ Intercept } & $(-1.26)$ & $(-1.57)$ & (1.63) & (1.65) \\
\hline & 0.208 & 0.116 & 0.102 & 0.099 \\
\hline & $.019 *$ & $.002 *$ & $-.007 *$ & $-.007 *$ \\
\hline \multirow[t]{3}{*}{ SIZE } & $(1.71)$ & (1.67) & $(-1.69)$ & $(-1.70)$ \\
\hline & 0.086 & 0.095 & 0.091 & 0.089 \\
\hline & .003 & .004 & $-.005^{*}$ & $-.005 *$ \\
\hline \multirow[t]{3}{*}{ MEETINGS } & (1.32) & (1.61) & $(-1.75)$ & $(-1.57)$ \\
\hline & 0.188 & 0.107 & 0.079 & 0.117 \\
\hline & .001 & .002 & -.006 & -.006 \\
\hline \multirow[t]{3}{*}{ COMMITTEES } & $(0.11)$ & $(0.30)$ & $(-0.60)$ & $(-0.57)$ \\
\hline & 0.913 & 0.764 & 0.546 & 0.568 \\
\hline & -.067 & -.071 & $.190 * *$ & $.196 * *$ \\
\hline \multirow[t]{3}{*}{ WOMAN } & $(-1.06)$ & $(-1.09)$ & $(2.30)$ & $(2.33)$ \\
\hline & 0.288 & 0.274 & 0.022 & 0.020 \\
\hline & $-.147 * *$ & & -.008 & \\
\hline \multirow[t]{2}{*}{ INDEPDIR } & $(-2.29)$ & & $(-0.07)$ & \\
\hline & 0.002 & & 0.946 & \\
\hline \multirow{6}{*}{ BINDEP } & & $-.066 * *$ & & .009 \\
\hline & & $(-2.03)$ & & $(0.25)$ \\
\hline & & 0.043 & & 0.805 \\
\hline & $\begin{array}{l}\text { Wald chi }{ }^{2} \\
=8.89\end{array}$ & $\begin{array}{l}\text { Wald chi }{ }^{2} \\
=7.72\end{array}$ & $\begin{array}{l}\text { Wald chi }{ }^{2} \\
=10.74^{*}\end{array}$ & $\begin{array}{l}\text { Wald chi }{ }^{2} \\
=10.83^{*}\end{array}$ \\
\hline & $(.1134)$ & $(.1725)$ & $(.0568)$ & $(.0548)$ \\
\hline & $\mathrm{R}^{2}: .068$ & $\mathrm{R}^{2}: .058$ & $\mathrm{R}^{2}: .139$ & $\mathrm{R}^{2}: .142$ \\
\hline
\end{tabular}

Random-effects GLS regression.

For a definition of the variables see Table 3 .

Significance level: ${ }^{*} p<.1,{ }^{* *} p<.05$
Table 5 shows the results about the relationship between the abnormal accruals and the six CG factors used as independent variables using random effects panel regression ${ }^{4}$. Due to the interrelationship between INDEPDIR and BINDEP, the second considered as a proxy of the first by some authors, two models have been defined introducing only one of the variables into each model (equations (2) and (3)).

For agencies that apply the PSCA, only coefficients for SIZE and board independence (INDEPDIR and BINDEP) are significant. For these entities, as the coefficient for SIZE is significant and positive, board size is positively associated with discretionary accruals, that is, the larger the number of directors on the board, the higher the discretionary accruals and, therefore, the lower the reliability of financial reports. So, Hypothesis 1 is not confirmed for this kind of agencies. INDEPDIR and BINDEP coefficients are negative and significant, that shows that board independence is negatively associated with discretionary accruals, confirming Hypothesis 4. If abnormal accruals impair the reliability of financial reports, then the negative sign of the INDEPDIR and BINDEP coefficients means that the higher the percentage of independent directors on the board of directors, the lower the discretionary accruals and, hence, the higher the reliability of financial reports. Analyzing this relationship for each year with OLS regression (not tabulated), the coefficient is significant for the period 2013-2015. For the period 2011-2012, even though the percentage of independent directors maintains its negative sign, it is not statistically significant. These were the worst years of the financial crisis in which central government revenues fell dramatically, as can be seen in Table 1, while, in 2013, these revenues maintained the previous levels or, as in 2015, started a weak upturn and independent directors were able to encourage the improvement of the reliability of financial performance figures.

In accordance with the Legitimacy and Stakeholders theories, the Size has been selected because it enables the involvement of a higher number of independent directors, thereby strengthening the social legitimacy and representativeness of the agency action. However, the overall consideration of the two significant variables in PSCA agencies shows that the Size, per se, does not guarantee the independence of the board of directors, may contribute the delegation of tasks and responsibilities to executive bodies, and increased transference cost (Jensen, 1993). Instead, the independence of the board and the number of independent directors, which contribute to the political and knowledge diversity, come up from the study as the critical factor for the improvement of the reliability of financial information.

For agencies that apply the PrCA, the significant coefficients are for SIZE, MEETINGS and WOMAN. The coefficient for SIZE is negative. Contrary to agencies that apply PSCA, in PrCA agencies board size is negatively associated with discretionary accruals, that is, the larger the number of directors on the board, the lower the discretionary accruals and, therefore, the higher the reliability of financial reports, confirming Hypothesis 1 . The coefficient for MEETINGS is negative, that is, the larger the number of meetings per year, the lower the discretionary accruals and, therefore, the higher the reliability of financial reports, confirming Hypothesis 2. Finally, for these entities, as the coefficient for WOMAN is positive, the proportion of women in the board is positively associated with discretionary accruals. Hypothesis 5 is not confirmed.

\footnotetext{
${ }^{4}$ To decide between fixed or random effects, we run the Hausman test (Greene, 1997). As Prob>chi2 yields values higher than 0.05 in all regressions, random effects are applied.
} 
Contrary to agencies that apply PSCA, in agencies that apply PrCA, the board independence is not associated with discretionary accruals. Finally, the number of committees in the board is not associated with discretionary accruals for any of both groups.

\section{Discussion}

The reliability of financial reports is considered a guiding principle of good governance and a tool to increase legitimacy and trust in government, as CG conformance postulates state. After the statements of public sector accounting and auditing institutions in favor of the applicability of CG postulates to the improvement of organizations' conformance and performance, very few empirical studies have been carried out to analyze how these CG features work in the public sector. In all the CG proposals, the board of directors plays a critical role in the control of CEOs and managerial actions. This study analyzes the effects of the size, composition and internal structures of the board of directors on the financial accountability of the agencies studied as a critical conformance aspect of CG for the effective monitoring and accountability of the managerial action.

The analysis carried out in this paper shows evidence of systematic upward earnings management activity for Spanish central government agencies that apply PrCA (business-like oriented) during the period 2011-2014 whereas the agencies that apply PSCA (public service oriented) do not show a clear pattern with respect to earnings management. This does not necessarily mean that there is no earnings management activity, but that there is no pattern of behavior (earnings increase or earnings decrease). So, a remarkable result is that the impact of CG features on the reliability of financial information disclosed is different depending on the type of agency (PSCA or PrCA). For PSCA agencies, there is a negative impact of the size of the boards of directors as well as a positive impact of independent directors on the boards of directors on the reliability of the financial information disclosed. For business-like agencies, there is a positive impact of the size of the boards of directors and a negative impact of the proportion of women on the reliability of the financial information. In this group, board independence is not related with financial information reliability. At central level, the governmental debt is managed by the General Directorate of Treasury Policy and central government agencies do not borrow at individual level. Furthermore, the PSCA agencies consolidate their financial statements with the central government financial statements, as parent entity, for calculating the net borrowing/net lending of Spain on ESA basis. For this purpose, the Treasury adjusts budgetary figures in order to turn them into national accounting figures. Therefore, PSCA agencies are likely to receive pressures from the Ministry of the Treasury to make that their accounting figures contribute to achieving the fiscal objectives agreed by the EU for Spain. Thus, only those entities with board of directors independent from their parent entity are better able to withstand this kind of pressures. Board independence is associated with lower discretionary accruals for public-service oriented agencies. In these cases, the presence of independent directors on the boards can enhance managerial monitoring and reduce information asymmetry which improves financial reporting quality.The PrCA agencies obtain more than $50 \%$ of their financial resources by the sale of the goods and services they produce and because of this their financial figures are not included in the calculation of the Spanish net borrowing/net lending. Therefore, they do not may receive the same strong pressure as PSCA agencies to make the accounting figures friendlier to the Ministry of Treasury needs, to meet the EU fiscal objectives.

With regard to the board size, the empirical research shows the need to find a balance between size and representativeness. In the PSCA agencies, larger boards (up to 61 members) do not benefit from their ability to include a wide range of stakeholders or to provide higher expertise and diversity for the financial reporting reliability. This is due to the fact that the costs outweigh the benefits or because the CEO may be more likely to control the board of directors. On the other hand, large boards of PrCA agencies, which are up to 21 members (30\% the size of PSCA agencies), benefit both from their ability to represent stakeholders and a size less expensive and easier to manage.

The agency, legitimacy and stakeholder theories are three of the most outstanding theories supporting CG postulates. The legitimacy and stakeholder theories attempt to overcome some criticisms of the agency theory with respect to its capacity for explaining board of director behavior. Limiting the scope of the study to principal-agent contracts is simplistic because the dynamics of interrelations between board directors and between directors and managers are more complex than that (Tricker, 2012). The legitimacy theory adopts a legalistic and normative perspective about board directors. The stakeholder theory expands this interest to all those affected by the decisions of the entity including citizens, taxpayers, lenders, local community, etc. (Demb \& Neubauer, 1992). This view opens the boards to independent directors, i.e., in the case of agencies, independent representatives of entities and/or institutions other than the central government parent entity. The results of our study show the critical role played by independent directors in monitoring the reliability of the financial reports and, thus, in holding managers accountable.

For CIPFA (1994) one of the major considerations of the Cadbury Committee was to examine the issue of the balance of power within entities. This balance is essentially obtained by ensuring that the elected members are separated from the officers appointed to implement and manage the policies of the entity. Independent directors are representatives of other public administrations, governed sometimes by different political parties and private sector stakeholders related to the activities and/or goals of the controlled entity. Independent members not involved in the management of the entity bring other perspectives to strategy development and decision-making, hold to the executive account for its performance (CIPFA, 2004). Therefore, the reliability of the financial reports seems to depend more on the members not appointed by the central government and not involved in the direct management of the controlled entity than on the control tools established through committees or the number of meetings.

The number of meetings is only occasionally significant and the number of board committees (which represent the control over CEOs and managers) is not significant.

\section{Conclusions}

The analysis carried out in this paper provides evidence of systematic upward earnings management activity by central government agencies that apply the Private Sector Chart of Accounts (business-like oriented agencies) to improve their financial performance and to compensate for the reduction of revenues during the worst years of the 2008 financial crisis. The results also show a different impact of CG features on financial reporting reliability. For agencies that apply the Public 
Sector Chart of Accounts (public-service oriented agencies), abnormal accruals have a significant and inverse relationship with the percentage of independent directors on the boards, as well as a positive relationship with the size of the boards of directors. This means that in public-service oriented agencies, the board independence from parent ministry improves the reliability of financial information useful for monitoring, accountability and decision-making purposes, and that very big boards reduce the reliability of financial information.

The composition of the boards of directors is revealed in this study as key to explaining the reliability of the financial reports of public-service oriented agencies. The variety of origins of the independent directors provides technical and ideological independence and background diversity. Therefore, independent directors will be more likely to enhance the reliability of financial reports used to hold these entities accountable. For business-like oriented agencies, abnormal accruals have a negative relationship with the size of the boards of directors and a positive relationship with the percentage of women in the board. The relationship between the size and composition of the board of directors, and the reliability of financial reports is important to practitioners, academics, and policy makers. Assumptions about both the importance of the reliability of financial reports in the public sector and the search for new governance styles are shaping current regulatory initiatives for the design of governance structures.

Functioning aspects of CG, such as the number of meetings and the number of committees, are not significant for explaining the reliability of the financial reports of the entities studied in both models. Committees may be controlled by internal members and the number of meetings, when the boards are big, might be ineffective for controlling purposes.

One limitation of this study is the absence of clear theories about CG, which could contribute to selecting the factors that explain CG. Future research in this field could extend this study to other public sector entities and to other European countries, in order to analyze the relationship between their CG structure and composition and the level of reliability of their financial reports.

\section{Funding}

The authors gratefully acknowledge financial support from the Ministerio de Economía y Competitividad (Proyecto I D i ECO2015-66240P) MINECO/FEDER, Gobierno de Aragón (Referencia Grupo S56_17R Gespública) and co-financed by Feder 2014-2020.

\section{Conflict of interests}

The authors declare no conflict of interests.

\section{References}

Agrawal, A., \& Chadha, S. (2005). Corporate governance and accounting scandals. Journal of Law \& Economics, 48(2), 371-406. https://doi.org/10.1086/430808

Agrawal, A., \& Knoeber, C. R. (1996). Firm performance and mechanisms to control agency problems between managers and shareholders. Journal of Financial and Quantitative Analysis, 31(3), 377-397. https://doi.org/10.2307/ 2331397

Allegrini, M., \& Greco, G. (2013). Corporate boards, audit committees and voluntary disclosure: evidence from
Italian listed companies. Journal of Management \& Governance, 17(1), 187-216. https://doi.org/10.1007/ s10997-011-9168-3

Allini, A., Rossi, F. M., \& Hussainey, K. (2016). The board's role in risk disclosure: An exploratory study of Italian listed state-owned enterprises. Public Money \& Management, 36(2), 113-120. https://doi.org/10.1080/ 09540962.2016 .1118935

Araujo, J. F. F. E., \& Tejedo-Romero, F. (2016). Women's political representation and transparency in local governance. Local Government Studies, 42(6), 885-906. https://doi. org/10.1080/03003930.2016.1194266

Arfken, D. E., Bellar, S. L., \& Helms, M. M. (2004). The ultimate glass ceiling revisited: The presence of women on corporate boards. Journal of Business Ethics, 50(2), 177-186. https://doi.org/10.1023/B:BUSI.0000022125. 95758.98

Ashforth, B. E., \& Gibbs, B. W. (1990). The double-edge of organizational legitimation. Organization Science, 1(2), 177-194. https://doi.org/10.1287/orsc.1.2.177

Ballantine, J., Forker, J., \& Greenwood, M. (2007). Earnings Management in English NHS Hospital Trusts. Financial Accountability and Management, 23(4), 421-440. https: //doi.org/10.1111/j.1468-0408.2007.00436.x

Bartov, E., Gul, F. A., \& Tsui, J. (2000). Discretionary-accruals models and audit qualifications. Journal of Accounting \& Economics, 30(3), 421-452. https://doi.org/10.1016/ S0165-4101(01)00015-5

Batley, R., \& Larbi, G. (2004). The Changing Role of Government: The Reform of Public Services in Developing Countries. New York, NY: Springer.

Beattie, V. (2002). Traditions of research in financial accounting. In B. Ryan, R. W. Scapens \& M. Theobald (Eds.), Research method and methodology in finance and accounting. London: Thomson.

Bhagat, S., \& Black, B. (1998). Board Independence and Long-term Performance. Columbia Law School, Center for Law and Economics Studies, WP No. 143.

Bhagat, S., \& Black, B. (2002). The non-correlation between board independence and long-term firm performance. Journal of Corporation Law, 27(2), 231-273. http://dx. doi.org/10.2139/ssrn.133808

Borisova, G., Brockman, P., Salas, J. M., \& Zagorchev, A. (2012). Government ownership and corporate governance: Evidence from the EU. Journal of Banking \& Finance, 36(11), 2917-2934. https://doi.org/10.1016/ j.jbankfin.2012.01.008

Brickley, J. A., \& Van Horn, R. L. (2002). Managerial incentives in nonprofit organizations: Evidence from hospitals. Journal of Law \& Economics, 45(1), 227-249. https: //doi.org/10.1086/339493

Byrd, J. W., \& Hickman, K. A. (1992). Do outside directors monitor managers - evidence from tender offer bids. Journal of Financial Economics, 32(2), 195-221. https: //doi.org/10.1016/0304-405X(92)90018-S

Calabro, A., Torchia, M., \& Ranalli, F. (2013). Ownership and control in local public utilities: The Italian case, Journal of Management and Governance, 17(4), 835-862. https: //doi.org/10.1007/s10997-011-9206-1

Capalbo, F., Frino, A., Mollica, V., \& Palumbo, R. (2014). Accrual-based earnings management in state owned companies Implications for transnational accounting regulation Accounting, Auditing \& Accountability Journal, 27(6), 1026-1040. http://dx.doi.org/10.1108/ AAAJ-06-2014-1744

Carcello, J. V., Hermanson, D. R., Neal, T. L., \& Riley, R. 
A. (2002). Board characteristics and audit fees. Contemporary Accounting Research, 19(3), 365-384. https: //doi.org/10.1506/CHWK-GMQ0-MLKE-K03V

Carter, D. A., Simkins, B. J., \& Simpson, W. G. (2003). Corporate Governance, Board Diversity, and Firm Value. Financial Review, 38(1), 33-53. https://doi.org/10.1111/ 1540-6288.00034

Cheng, E., \& Courtenay, S.M. (2006). Board composition, regulatory regime and voluntary disclosure. International Journal of Accounting, 41(3), 262-289. https://doi.org/ 10.1016/j.intacc.2006.07.001

Chin, T., Vos, E., \& Casey, Q. (2003). Levels of Ownership Structure, Board Composition and Board Size Seem Unimportant in New Zealand. Ownership and Control, 2(1), 119-128. https://doi.org/10.22495/cocv2i1p9

Christopher, J. (2010). Corporate governance-A multitheoretical approach to recognizing the wider influencing forces impacting on organizations. Critical Perspectives on Accounting, 21(8), 683-695. https://doi.org/10.1016/j. cpa.2010.05.002

CIPFA. (1994). Corporate Governance in the Public Services. London: Chartered Institute of Public Finance and Accountancy.

CIPFA. (1995). Good Governance Standard for Public Services. London: Chartered Institute of Public Finance and Accountancy.

CIPFA. (2004). Good Governance Standard for Public Services. London: Chartered Institute of Public Finance and Accountancy.

Coffey, B. S., \& Wang J. (1998). Board Diversity and Managerial Control as Predictors of Corporate Social Performance. Journal of Business Ethics, 17(4), 1595-1603. https://doi.org/10.1023/A:1005748230228

Coy, D., \& Dixon K. (2004). The public accountability index: crafting a parametric disclosure index for annual reports. British Accounting Review, 36(1), 79-106. https: //doi.org/10.1016/j.bar.2003.10.003

Coy, D., Fischer, M., \& Gordon, T. (2001). Public accountability: a new paradigm for college and university annual reports. Critical Perspectives on Accounting, 12(1), 1-31. https://doi.org/10.1006/cpac.2000.0416

Daily, C. M., \& Dalton, D. R. (1992). The Relationship between Governance Structure and Corporate. Performance in Entrepreneurship Firms. Journal of Business Venturing, 7(5), 375-386. https://doi.org/10.1016/ 0883-9026(92)90014-I

De Pablo, A., Azofra, V., \& Lopez, F. (2005). Corporate Boards in OECD Countries: size, composition, functioning and effectiveness. Corporate Governance, 13(2), 197-210. https://doi.org/10.1111/j.1467-8683.2005.00418.x

Dechow, P. M., Sloan, R. G., \& Sweeney, A. P. (1995). Detecting earnings management. The Accounting Review, 70(2), 193-225. http://www.jstor.org/stable/248303

Demb, A., \& Neubauer, F. (1992). The Corporate Board: Confronting the Paradoxes. NY: Oxford University Press.

Denis, D., \& Sarin, A. (1999). Ownership and Board Structures in Publicly Traded Corporations. Journal of Financial Economics, 52(2), 187-224. https://doi.org/10. 1016/S0304-405X(99)00008-2

Donaldson, T., \& Preston, L.E. (1995). The stakeholder theory of the corporation: concepts, evidence and implications. Academy of Management Review, 20(1), 65-91. https://doi.org/10.5465/amr.1995.9503271992

Ellwood, S., \& Garcia-Lacalle, J. (2015). The influence of presence and position of women on the boards of directors: the case of NHS foundation trusts. Journal of
Business Ethics, 130(1), 69-84. https://doi.org/\%5B10. 1007/s10551-014-2206-8\%5D

Filgueiras, F. (2015). Transparency and accountability: principles and rules for the construction of publicity. Journal of Public Affairs, 16(2), 192-202. https://doi.org/10. 1002/pa.1575

Ferreira, A., Carvalho, J., \& Pinho, F. (2009). Earnings Management in Municipalities, Paper presented to the 32nd European Accounting Association Conference, Tampere 12-15 May.

Freeman, R. E. (1984). Strategic Management: A Stakeholder Approach. Boston, MA: Pitman.

Freeman, R. E., \& Reed, D. L. (1983). Stockholders and stakeholders: a new perspective on corporate governance. California Management Review, 25(3), 88-106. https:// doi.org/10.2307/41165018

Gaio, C. \& Pinto, I. (2018). The role of state ownership on earnings quality: evidence across public and private European firms Journal of Applied Accounting Research Vol. 19 No. 2, 2018 pp. 312-332. https://doi.org/10.1108/ JAAR-07-2016-0067

Gnan, L., Hinna, A., Monteduro, F., \& Scarozza, D. (2011). SOEs ownership and control: independence and competence of boards members. Corporate Ownership \& Control, 8(1), 720-739. https://doi.org/10.22495/cocv8i1c7p6

Goodstein, J., Gautam, K., \& Boeker, W. (1994). The Effects of Board Size and Diversity on Strategic Change. Strategic Management Journal, 15(3), 241-250. https://doi.org/ 10.1002/smj.4250150305

Greene, W.H. (1997). Econometric analysis. $3^{\text {rd }}$ edition. Upper Saddle River (New Jersey): Prentice-Hall International.

Healy, P., \& Wahlen, J. (1999). A Review of the Earnings Management Literature and its Implications for Standard Setting. Accounting Horizons, 13(4), 365-383. https:// doi.org/10.2308/acch.1999.13.4.365

Hinna, A., De Nito, E., \& Mangia, G. (2010). Board of directors within public organisations: a literature review, International Journal of Business Governance and Ethics, 5(3), 131-156. https://doi.org/10.1504/IJBGE.2010.033343

Hodges, R., Wright, M., \& Keasey, K. (1996). Corporate Governance in the Public Services: Concepts and Issues, Public Money \& Management, 16(2), 7-13. https://doi.org/ 10.1080/09540969609387915

Hossain, M., Prevost, A. K., \& Rao, R. P. (2001). Corporate Governance in New Zealand: The Effect of the 1993 Companies Act on the Relation between Board Composition and Firm Performance. Pacific-Basin Finance Journal, 9(2), 119-145. https://doi.org/\%5B10.1016/ S0927-538X(01)00003-8\%5D

Hribar, P., \& Collins, D.W. (2002). Errors in Estimating Accruals: Implications for Empirical Research. Journal of Accounting Research, 40(1), 105-134. https://doi.org/10. 1111/1475-679X.00041

Jensen, M. C. (1993). The Modern Industrial Revolution, Exit, and the Failure of Internal Control Systems. Journal of Finance, 48(3), 831-880. https://doi.org/10.1111/j. 1540-6261.1993.tb04022.x

Jensen M. C., \& Meckling, W. H. (1976). Theory of the firm: managerial behavior, agency costs and ownership structure. Journal of Financial Economics, 3(4), 305-360. https://doi.org/10.1016/0304-405X(76)90026-X

Jones, J. J. (1991). Earnings Management During Import Relief Investigations. Journal of Accounting Research, 29(2), 193-228. https://doi.org/10.2307/2491047

Karamanou, I., \& Vefeas, N. (2005). The association between 
corporate boards, audit committees, and management earnings forecasts: an empirical analysis. Journal of Accounting Research, 43(3), 453-486. https://doi.org/10. 1111/j.1475-679X.2005.00177.x

Kasznik, R. (1999). On the Association between Voluntary Disclosure and Earnings Management. Journal of Accounting Research, 37 (1), 57-81. https//doi.org/10.2307/2491396

Klein, A. (1998). Firm performance and board committee structure. Journal of Law and Economics, 41(1), 275-303. https://doi.org/10.1086/467391

Klein, A. (2002). Audit committee, board of director characteristics, and earnings management. Journal of Accounting and Economics, 33(3), 375-400. https://doi.org/10. 1016/S0165-4101(02)00059-9

Lane, J. E. (2005). Public Administration and Public Management: The Principal-Agent Perspective. New York, NY: Taylor \& Francis.

Larcker, D., Richardson, S., \& Tuna, I. (2007). Corporate governance, accounting out comes and organizational performance. The Accounting Review, 82(4), 963-1008. https://doi.org/10.2308/accr.2007.82.4.963

Leone, A. J., \& Van Horn, R. L. (2005). How do nonprofit hospitals manage earnings? Journal of Health Economics, 24(4), 815-837. https://doi.org/10.1016/j.jhealeco. 2005.01.006

Lipton, M., \& Lorsch, J. W. (1992). A Modest Proposal for Improved Corporate Governance. Business Lawyer, 48(1), 59-77. https://www.jstor.org/stable/i40030117

Mace, M. L. (1986). Directors: Myth and Reality. Boston, MA: Harvard Business School Press.

Mahadeo, J. D., Oogarah-Hanuman, V., \& Soobaroyen, T. (2011). A longitudinal study of corporate social disclosures in a developing economy. Journal of Business Ethics, 104(4), 545-558. https://doi.org/10.1007/ s10551-011-0929-3

McMullen, D. A. (1996). Audit Committee Performance: An Investigation of the Consequences Associated with Audit Committees. Auditing, 15(1), 87-103.

Michelon, G., \& Parbonetti, A. (2012). The effect of corporate governance on sustainability disclosure. Journal of Management \& Governance, 16(3), 477-509. https: //doi.org/10.1007/s10997-010-9160-3

NAO. (2003). Improving Service Delivery: The Role of Executive Agencies. Report by the Comptroller and Auditor General HC 525 Session 2002-2003: 28 March 2003 (London).

NAO. (2016). Departments' oversight of arm's-length bodies: a comparative study. Report by the Comptroller and Auditor General HC 507 Session 2016-17: 5 July 2016 (London).

Nolan. (1995). First Report of the Committee on Standards of Public Life. Cmnd 2850(1). London: HMSO.

Normanton, E. L. (1971). Public accountability and audit: a reconnaissance. In B.R. Smith \& D.C. Hague (Eds.), The Dilemma of Accountability in Modern Government: Independence Versus Control (pp. 311-345). London: Macmillan.

Ntim, C. G., Soobaroyen, T., \& Broad, M. J. (2017). Governance structures, voluntary disclosures and public accountability the case of UK higher education institutions. Accounting Auditing \& Accountability Journal, 30(1), 65118. https://doi.org/10.1108/AAAJ-10-2014-1842

OECD. (2005). Modernising Government: The Way Forward. Paris: OECD.

Pilcher, R., \& Van der Zahn, M. (2010). Local Govern- ments, Unexpected Depreciation and Financial Performance Adjustment. Financial Accountability and Management, 26(3), 299-324. https://doi.org/10.1111/j. 1468-0408.2010.00503.x

Pina, V., Torres, L., \& Yetano, A. (2009). Accrual Accounting in EU Local Governments: One method, several approaches. European Accounting Review, 18(4), 765-807. https://doi.org/10.1080/09638180903118694

Pina, V., Arcas, M. J., \& Marti, C. (2012). Accruals and Accounting Numbers Management in the UK Executive Agencies. Public Money and Management, 32(4), 273-280. https://doi.org/10.1080/09540962.2012.691306

Reddy, K., Locke, S., \& Scrimgeour, F. (2011). Improving performance in New Zealand's public corporations: The effect of governance practices. Governance-an International Journal of Policy Administration and Institutions, 24(3), 517-556. https://doi.org/10.1111/j.1468-0491. 2011.01537.x

Reddy, K., Locke, S., Scrimgeour, F., \& Gunasekarage, A. (2008). Corporate Governance Practices of Small Cap Companies and Their Financial Performance: An Empirical Study in New Zealand. International Journal of Business Governance and Ethics, 1(4), 51-78. https://doi.org/ 10.1111/j.1468-0491.2011.01537.x

Reguera Alvarado, N., Laffarga Briones, J., \& de Fuentes Ruiz, P. (2015). Earnings management models: A transnational study. Revista De Contabilidad-Spanish Accounting Review, 18(1), 11-19. https://doi.org/10.1016/j. rcsar.2.14.01.001

Rosenstein, S., \& Wyatt, J. G. (1990). Outside directors, board independence, and shareholder wealth. Journal of Financial Economics, 26(2), 175-191. https://doi.org/10. 1016/0304-405X(90)90002-H

Royo, S, Yetano, A \& García-Lacalle, J. (2019). Accountability Styles in State-Owned enterprises: The good, the bad, the ugly ... And the pretty, Revista de Contabilidad Spanish Accounting Review 22 (2), 156-170. https: //doi.org/10.6018/rcsar.382231

Shawtari, F. A., Mohamad, M. H. S., Rashid, H. M. A., \& Ayedh, A. M. (2017). Board characteristics and real performance in Malaysian state-owned enterprises (SOEs). International Journal of Productivity and Performance Management, 66(8), 1064-1086. https://doi.org/ 10.1108/IJPPM-12-2015-0188

Stalebrink, O. J. (2007). An investigation of discretionary accruals and surplus-deficit management: Evidence from Swedish Municipalities. Financial Accountability and Management, 23(4), 441-458. ttps://doi.org/10.1111/j.1468-0408.2007.00437.x

Suchman, M. C. (1995). Managing legitimacy: strategic and institutional approaches. Academy of Management Review, 20(3), 571-606. https://doi.org/10.5465/amr. 1995.9508080331

Tricker, B. (2012). Corporate Governance. Principles, Policies and Practices. Oxford University Press.

Trussel, J. (2003). Assessing Potential Accounting Manipulation: The Financial Characteristics of Charitable Organizations with Higher than Expected Program-Spending Ratios. Nonprofit and Voluntary Sector Quarterly, 32(4), 616634. https://doi.org/10.1177/0899764003257459

Tucker, J. W., \& Zarowin, P. A. (2006). Does income smoothing improve earnings informativeness? The Accounting Review, 81(1), 251-270. https://doi.org/10.2308/accr. 2006.81.1.251

Van Knippenberg, D., De Dreu, C. K. W., \& Homan, A. C. (2004). Work Group Diversity and Group Performance: 
An Integrative Model and Research Agenda. Journal of Applied Psychology, 89(6), 1008-1022. https://doi.org/ 10.1037/0021-9010.89.6.1008

Vafeas, N. (2005). Audit committees, boards, and the quality of reported earnings. Contemporary Accounting Research, 22(4), 1093-1122. https://doi.org/10.1506/ $1 \mathrm{QYN}-2 \mathrm{RFQ}-\mathrm{FKYX}$-XP84

Verbruggen, S., \& Christiaens, J. (2012). Do non-profit organizations manage earnings toward zero profit and does governmental financing play a role? Canadian Journal of Administrative Sciences-Revue Canadienne Des Sciences De L Administration, 29(3), 205-217. https://doi.org/10. 1002/CJAS.1219

Wang, L and Yung, K. (2011). Do State Enterprises Manage Earnings More than Privately Owned Firms? The Case of China. Journal of Business Finance \& Accounting, 38(7) \& (8), 794-812. https://doi.org/10.1111/j.1468-5957. 2011.02254.X

Watts, R. L., \& Zimmerman, J. L. (1986). Positive Accounting Theory. London: Prentice-Hall International.

Yermack, D. (1996). Higher market valuation of companies with a small board of directors. Journal of Financial Economics 40(2), 185-211. https://doi.org/10.1016/ 0304-405X(95)00844-5 